\title{
Anthocyanins in Colorectal Cancer Prevention Review
}

\author{
Ni Shi ${ }^{1,2}$, Xiaoxin Chen ${ }^{3}$ and Tong Chen ${ }^{1,2, *}$ \\ 1 Department of Internal Medicine, Division of Medical Oncology, The Ohio State University, \\ 1800 Cannon Drive, 13th Floor, Columbus, OH 43210, USA; ni.shi@osumc.edu \\ 2 Comprehensive Cancer Center, The Ohio State University, Columbus, OH 43210, USA \\ 3 Cancer Research Program, Julius L. Chambers Biomedical Biotechnology Research Institute, \\ North Carolina Central University, 700 George St., Durham, NC 27707, USA; lchen@nccu.edu \\ * Correspondence: tong.chen@osumc.edu; Tel.: +1-(614)-685-9119
}

check for updates

Citation: Shi, N.; Chen, X.; Chen, T. Anthocyanins in Colorectal Cancer Prevention Review. Antioxidants 2021, 10, 1600. https://doi.org/10.3390/ antiox 10101600

Academic Editor: Stanley Omaye

Received: 23 May 2021

Accepted: 11 October 2021

Published: 12 October 2021

Publisher's Note: MDPI stays neutral with regard to jurisdictional claims in published maps and institutional affiliations.

Copyright: (c) 2021 by the authors. Licensee MDPI, Basel, Switzerland This article is an open access article distributed under the terms and conditions of the Creative Commons Attribution (CC BY) license (https:// creativecommons.org/licenses/by/ $4.0 /)$.

\begin{abstract}
Colorectal cancer (CRC) is still a big health burden worldwide. Nutrition and dietary factors are known to affect colorectal cancer development and prognosis. The protective roles of diets rich in fruits and vegetables have been previously reported to contain high levels of cancer-fighting phytochemicals. Anthocyanins are the most abundant flavonoid compounds that are responsible for the bright colors of most blue, purple, and red fruits and vegetables, and have been shown to contribute to the protective effects of fruits and vegetables against cancer and other chronic diseases. Berries and grapes are the most common anthocyanin-rich fruits with antitumor effects. The antitumor effects of anthocyanins are determined by their structures and bioavailability as well as how they are metabolized. In this review, we aimed to discuss the preventive as well as therapeutic potentials of anthocyanins in CRC. We summarized the antitumor effects of anthocyanins and the mechanisms of action. We also discussed the potential pharmaceutical application of anthocyanins in practice.
\end{abstract}

Keywords: colorectal cancer; anthocyanins; phytochemicals; berries; grapes; antitumor effect

\section{Introduction}

Colorectal cancer (CRC) is the third most common tumor and the second leading lethal tumor worldwide [1]. The risk factors for CRC include heritable genetic changes, environmental and food-borne mutagens, excess weight and obesity, inflammatory bowel disease, heavy alcohol use, smoking, physical inactivity, compromised gut microbiota, and poor diet. Nutrition and dietary factors are known to affect CRC. Epidemiological investigations have revealed that diets high in fruits, vegetables, and whole grains are associated with reduced risk of CRC, while diets high in red and processed meat are associated with increased risk [2]. The American Cancer Society recommends limiting the intake of red and processed meats and eating more vegetables and fruits to help lower the risk of CRC. The protective roles of diets rich in fruits and vegetables have been previously reported. Fruit and vegetable-rich diets are associated with reduced oxidation, DNA damage, cell growth inhibition, cell cycle arrest, and low-grade inflammation as well as the promotion of beneficial gut microbiota [3]. Phytochemicals, naturally occurring plant chemicals that provide fruits and vegetables with color, odor, and flavor, show the potential to reduce oxidative stress, prevent DNA damage, impact DNA repair, slow cancer cell growth, promote cancer cell death, reduce inflammation, and boost immune function [4]. The most popular types of phytochemicals reported exhibiting anticancer efficacy contain carotenoids, flavonoids, isoflavones, polyphenols, and isothiocyanates. Anthocyanins are the most abundant flavonoid compounds that are responsible for the colors of most fruits and vegetables, and they contribute to the protective effects of fruits and vegetables against chronic diseases and cancer [5].

Anthocyanins are derived from flavonol with a basic structure of a flavylium ion lacking a ketone oxygen at the 4-position [6,7]. Depending on their skeleton, there are six 
different types of anthocyanidins: cyanidin, delphinidin, pelargonidin, peonidin, petunidin, and malvidin (Figure 1) [5]. Cyanidin is the major magenta pigment in berries and some red-colored vegetables such as purple corn, purple sweet potato, and red sweet potato. Delphinidin is a blue-reddish or purple pigment in the plant. Pelargonidin is the red-colored pigment in some fruits and berries. Peonidin, malvidin, and petunidin are three methylated anthocyanidins. Peonidin exists abundantly in berries, grapes, and red wines. Malvidin, the purple pigment, is the major dark-red pigment in natured red wine. Petunidin is a dark red or purple water-soluble pigment detected in black currants and purple flower petals. Anthocyanins carry different glucosides as the glycosylated form of anthocyanidin. Usually, the glucoside group of anthocyanins conjugate to the anthocyanidin skeleton via the $\mathrm{C} 3$ hydroxyl group in ring $\mathrm{C}$. The most commonly found glucosides that bond to anthocyanidins have glucose (glc), galactose (gal), arabinose (ara), rutinose (rut), rhamnose (rham), and xylose (xyl) in mono-, di-, or trisaccharide forms [8].

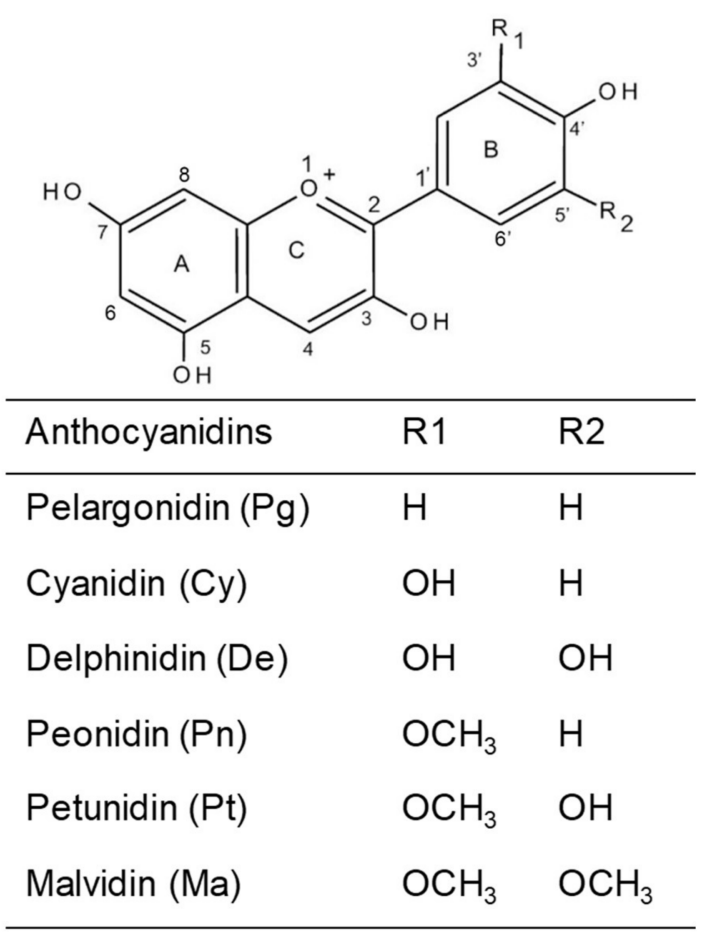

Figure 1. The structural classification of the six most common anthocyanins.

The chemical structure of anthocyanins is significantly associated with their stability and bioavailability, both of which determine their health benefits. Most anthocyanins are not stable and are sensitive to light, temperature, $\mathrm{pH}$, enzymes, oxygen, antioxidants, and other factors, necessitating high standards for the anthocyanin regimen and supplement product.

The bioavailability and metabolism of anthocyanins are of great research interest in biomedicine, clinic, and pharmacology. The rate and extent of anthocyanin absorption are affected by the anthocyanidin, sugar moiety, and acylated groups in the chemical structure. Anthocyanins can be absorbed via the mouth, stomach, and small intestine. Anthocyanins can be taken up, hydrolyzed, and conjugated by oral epithelial cells, and oral bacteria [9]. Anthocyanins can permeate the gastric mucosa through a bilitranslocase-mediated mechanism [10]. Anthocyanin glycosides can be rapidly and efficiently absorbed in the small intestine, involving transportation mechanisms such as glucose transporter SGLT1, glucoseassociated transporters (GLUTs), and intestinal bilitranslocase [10-13]. In the colon, the absorption of anthocyanins is zero, but the metabolism of anthocyanins will occur due to spontaneous degradation under physiological conditions or microbial metabolism [11,14]. However, only a small amount of anthocyanins can be found in the circulatory system and 
in the urine. The gap between the poor bioavailability and the positive health effects of anthocyanins is still a big challenge for the pharmacology research and development of anthocyanin-derived drugs. Extensive first-pass metabolism of anthocyanins is one of the reasons for the poor bioavailability, which means that most anthocyanins enter the circulatory system as metabolites $[8,11,12,15]$. The total bioavailability of anthocyanins should be higher than the estimated approximate $1 \%$ in previous reports when accounting for unmetabolized parent compounds, phase I and phase II metabolites, conjugated products, and microbe-generated metabolites $[8,11,12,15]$. However, the complex mixtures of unmetabolized parent anthocyanins, phenolic degradation products, glucuronide conjugates, sulfides conjugates, and post-colonic bacterial metabolites may coexist in the biofluids and tissues. Which anthocyanins are subject to the specific metabolism is not well known, and the technology to detect all the metabolites is also limited. Scientific understanding of the bioavailability and metabolism of anthocyanins is constantly evolving.

In our former studies, we demonstrated the cancer preventive effects of strawberries and black raspberries in colon cancer and esophageal cancer and found that anthocyanins are the main components in both fruits $[16,17]$. The roles of strawberry and black raspberry (BRB) extracts and anthocyanin compounds in colon cancer cell lines or animal models are summarized in our latest review on strawberries and BRB in inflammation-related CRC prevention [5]. Anthocyanins exist abundantly in fruits, vegetables, legumes, nuts, tea, and wine. Aside from strawberries and BRB, other fruits and vegetables rich in anthocyanins such as cherry, grape, pomegranate, purple sweet potato, eggplant, and some dark leafy greens also showed anticancer effects against CRC in both in vitro and in vivo models $[16,17]$. In this review, we summarize the anticancer effects of anthocyanins in $\mathrm{CRC}$, and then discuss the pharmaceutical application of anthocyanins in CRC prevention and therapy.

\section{Anthocyanins in Colon Cancer Prevention}

\subsection{Epidemiology Study}

Some epidemiology studies have found an inverse association between the high consumption of anthocyanins and the decreased risk of CRC. A large multicentric case-control study conducted in Italy found a significant inverse relationship between anthocyanidins and CRC, with a hazard ratio of 0.78 (95\% CI, 0.61-0.99) adjusting age, sex, fruit and vegetable intake, BMI, physical activity, alcohol intake, and education level [18]. In another case-control study in China, no significant association was found between the total flavonoid intake and CRC risk, but an inverse association between anthocyanidins and CRC risk was verified with an adjusted OR of $0.80(95 \%$ CI $0.64,1.00)$ for the highest quartile for anthocyanidin consumption compared with the lowest quartile [19]. However, other studies have shown no association between anthocyanin intake and CRC risk [20-23]. A more recent meta-analysis indicates that anthocyanin consumption is inversely associated with the risk of developing CRC with a pooled RR at 0.78 (95\% CI, 0.64-0.95) [24]. Regarding the critical roles of systematic review and meta-analysis in evidence-based medicine, this finding significantly supports the active role of anthocyanins in CRC prevention.

\subsection{Anthocyanin-Rich Whole Fruits and Vegetables in Colon Cancer Prevention}

In our previous study, we detected the role of lyophilized strawberries in azoxymethane $(\mathrm{AOM}) /$ dextran sodium sulfate (DSS)-induced and inflammation-associated colon carcinogenesis in the murine model. We found that strawberries decreased tumor incidence, reduced a bundle of proinflammatory mediators, and the nitrosative stress, at least, through inhibiting phosphatidylinositol 3-kinase (PI3K) / AKT and nuclear factor kappa B (NFkB) signaling cascades, as indicated in Table 1 [16]. Other groups also found that lyophilized blackberries and strawberries reduce the tumor multiplicity and pro-inflammatory gut bacteria in the AOM/DSS murine model [25]. In our recently published review, we summarized the roles of strawberries, $\mathrm{BRB}$, and anthocyanin components in the chemoprevention of inflammatory bowel disease (IBD)-related CRC [5]. In the rat model of colitis-associated 
carcinogenesis induced by 1,2-dimethylhydrazine (DMH) and 2,4,6-trinitrobenzene acid (TNBS), lyophilized acai pulp can reduce aberrant crypt foci (ACF) multiplicity, tumor cell proliferation, and incidence of tumors with high-grade dysplasia [26]. IBD patients are at an increased risk of developing CRC. CRC that develops in IBD patients tends to have a worse prognosis and survival rate compared to patients with sporadic CRC in the advanced stage. Compared to the modest efficiency of some chemical inhibitors, the anthocyanin-rich whole fruits showed better efficiency in preventing CRC in IBD patients due to additive and synergistic activities of multiple bioactive phytochemicals [5].

For sporadic CRC, BRB showed preventive effects in the non-inflammation-promoted CRC model, the AOM rat model. BRB decreased the ACF burden, ACF, and adenocarcinoma multiplicities, and reduced urinary 8-hydroxy-2'-deoxyguanosine (8-OHdG) levels [27]. Pomegranate and baked purple potato were also shown to prevent CRC development in the AOM-induced CRC in animals. Pomegranate juice suppressed the number of ACF and dysplastic ACF, lowered proliferation of mucosa cells and decreased expression levels of cyclooxygenase-2 (COX-2), inducible nitric oxide synthase (iNOS), NF- $\mathrm{kB}$ (p65), and vascular cell adhesion molecule 1 (VCAM-1) [28]. Baked purple potato suppressed the tumor incidence, promoted apoptosis, and increased cancer stem cell markers [29]. Apc $\mathrm{Ain}^{\mathrm{Min}}$ mouse is a popular animal model for studies of human colon cancer. With a mutation in the APC gene, the primary phenotype of Apc ${ }^{\mathrm{Min}}$ mice is the development of multiple intestinal adenomas [30]. Tart cherry significantly decreased the number and volume of adenomas in $\mathrm{Apc}^{\mathrm{Min}}$ mice [31]. As in IBD-related CRC, anthocyanin-rich whole fruits and vegetables are efficient strategies to prevent sporadic CRC.

Table 1. Anthocyanin-rich whole fruits and vegetables in colon cancer prevention.

\begin{tabular}{|c|c|c|c|}
\hline Fruit & Model & Findings & Ref. \\
\hline Lyophilized strawberries & AOM/DSS mouse & $\begin{array}{l}\text { Decreased tumor incidence; reduced } \\
\text { pro-inflammatory mediators and nitrosative } \\
\text { stress; decreased PI3K/AKT signaling and } \\
\text { NFkB }\end{array}$ & [16] \\
\hline $\begin{array}{l}\text { Lyophilized blackberriesand } \\
\text { strawberries }\end{array}$ & $\mathrm{AOM} / \mathrm{DSS}$ rat & $\begin{array}{l}\text { Reduced the tumor number; reduced } \\
\text { pro-inflammatory gut bacterial }\end{array}$ & [25] \\
\hline Lyophilized acai pulp & $\begin{array}{l}\text { 1,2-dimethylhydrazine }(\mathrm{DMH}) \\
\text { and 2,4,6-trinitrobenzene acid } \\
\text { (TNBS) rat }\end{array}$ & $\begin{array}{l}\text { Reduces the total number of ACF, ACF } \\
\text { multiplicity, tumor cell proliferation and } \\
\text { incidence of tumors with high-grade dysplasia }\end{array}$ & [26] \\
\hline BRB & AOM rat & $\begin{array}{l}\text { Decreased ACF burden and aberrant crypt } \\
\text { multiplicity; decreased adenocarcinoma } \\
\text { multiplicity; reduced urinary 8-OHdG levels }\end{array}$ & [27] \\
\hline Pomegranate juice & AOM rat & $\begin{array}{l}\text { Suppressed the number of ACF and dysplastic } \\
\text { ACF; lowered proliferation of mucosa cells; } \\
\text { decreased expression of COX-2, iNOS, NF-kB } \\
\text { (p65) and VCAM-1 }\end{array}$ & [28] \\
\hline Baked purple potato & AOM mouse & $\begin{array}{l}\text { Suppressed tumor incidence; promoted } \\
\text { apoptosis; increased cancer stem cell markers }\end{array}$ & [29] \\
\hline Tart cherry & APC mouse & $\begin{array}{l}\text { Decreased the number and volume of } \\
\text { adenomas }\end{array}$ & [31] \\
\hline
\end{tabular}

\subsection{Anthocyanin Extract in Colon Cancer Prevention}

The pros for whole foods in animal studies are the additive and synergistic activities of multiple bioactive phytochemical profiles. These pros are also cons for the whole food study, as it is unclear as to which components are responsible for chemoprevention. We considered anthocyanins to be largely responsible for the chemoprevention effects of anthocyanin-rich fruits and vegetables. The anthocyanin extract from these foods showed 
significant efficiency in preventing colon cancer in cell lines, animal models, and clinical trials (Table 2).

\subsubsection{Black Raspberry}

In CRC cell lines, the anthocyanin-enriched extract of BRB can suppress cell proliferation, induce apoptosis, and decrease the activity of DNMT1 and DNMT3B, and demethylate CDKN2A, SFRP2, SFRP5, and WIF1 in the Wnt pathway [32,33]. In the AOM/DSS colon cancer mouse model, the BRB anthocyanin extraction in the diet decreased tumor multiplicity, modulated the composition of gut commensal microbiota, and changed the inflammation index and the methylation status of the SFRP2 gene [34].

\subsubsection{Blueberry}

Blueberry extract inhibited the cell proliferation of Caco-2 cells with an $\mathrm{IC}_{50}$ at $0.78 \pm 0.15 \mathrm{mM}[35,36]$. In addition, blueberry extract inhibited cell proliferation and promoted apoptosis in HCT116 and HT-29 cells [33,36]. Compared to phenolic acids, tannins, and flavonol components, the blueberry anthocyanin extract showed the greatest antiproliferation effects. The anthocyanin extract from China blueberry (Vaccinium uliginosum L) inhibited proliferation in DLD-1 and COLO205 cells [37].

\subsubsection{Bilberry}

The bilberry anthocyanin extract showed antioxidative activity in Caco-2 cells, with an $\mathrm{IC}_{50}$ at $0.53 \pm 0.04 \mathrm{mM}$ [35]. Bilberry showed an antiproliferation effect in HT-19 cells and the mechanisms associated with increasing the expression of p21 [38-40]. Bilberry anthocyanin extract induced mitochondrial damage, activated apoptosis, inhibited cell proliferation in the mouse colon cancer cell line MC38 [41]. Bilberry extract has the potential to reduce the side effects of some chemotherapy drugs by suppressing the activity of topoisomerase I and the DNA strand breaks [42]. In the AOM/DSS-induced and IBDrelated CRC mouse model, the bilberry anthocyanin extract decreased the tumor number and inflammation [43]. In the AOM rat model, the bilberry extract was shown to reduce total ACF, colonic cellular proliferation, and COX-2 mRNA expression [44].

\subsubsection{Cranberry}

The cranberry anthocyanin extract inhibited the cell proliferation of HT-29, SW620, and SW480 cells derived from the primary tumor and the metastatic site of the same patient with CRC $[33,45]$. Interestingly, the cranberry anthocyanin extract exhibited more potent inhibitory effects in the progressive and metastatic SW620 cells, but not SW480 cells [45].

\subsubsection{Chokeberry}

The chokeberry anthocyanin extract inhibited the growth of HT-29 cells [38,40], and reduced the total number of ACF and colonic cellular proliferation in the AOM rat model [44]. A special black chokeberry (Aronia meloncarpa E) exhibited antioxidative effects, inhibited cell growth, promoted cell phase arrest, and upregulated several cell cycle-related genes [46-49].

\subsubsection{Blackberry}

The blackberry anthocyanin extract showed antioxidant, antiproliferative, and antiinflammatory activities in HT-29 and Caco- 2 cells by inhibiting cell growth and interleukin (IL)-12 release from mouse bone marrow-derived dendritic cells $[33,50,51]$.

\subsubsection{Other Berries}

Other berries like red raspberry and strawberry extract, lingonberry, elderberry, and black currant showed antitumor effects in CRC cell lines by inhibiting cell growth and promoting cell apoptosis $[33,52]$. The anthocyanin extract from flowering plant berries 
such as Prunus spinosa drupes (blackthorn) could inhibit the growth and colony formation, promote apoptosis in HCT-116 cells, and reduce tumor growth in xenograft mice [53].

Table 2. Whole fruit with anthocyanin components in colon cancer prevention.

\begin{tabular}{|c|c|c|c|}
\hline Source & Model & Finds & Ref. \\
\hline BRB & AOM/DSS mouse & $\begin{array}{l}\text { Decreased tumor multiplicity; modulated } \\
\text { the composition of gut commensal } \\
\text { microbiota }\end{array}$ & [34] \\
\hline $\mathrm{BRB}$ & $\begin{array}{l}\text { HT-29, HCT116, Caco2, and } \\
\text { SW } 480 \text { cells }\end{array}$ & $\begin{array}{l}\text { Inhibited cell growth; promoted } \\
\text { apoptosis; suppressed demethylation } \\
\text { effects }\end{array}$ & {$[32,33]$} \\
\hline Blueberry & $\begin{array}{l}\text { HT-29, HCT116, and Caco-2 } \\
\text { cells }\end{array}$ & $\begin{array}{l}\text { Inhibited cell growth; promoted } \\
\text { apoptosis }\end{array}$ & {$[33,35,36]$} \\
\hline Vaccinium uliginosum $\mathrm{L}$. & DLD- 1 and COLO205 cells & Inhibited cell proliferation & [37] \\
\hline Bilberry & Caco-2, HT-29, and MC38 cells & $\begin{array}{l}\text { Antioxidative; induced mitochondrial } \\
\text { damage; activated cell apoptosis; } \\
\text { inhibited cell growth; suppressed the } \\
\text { activity of topoisomerase I; suppressed } \\
\text { strand-breaking effects }\end{array}$ & {$[35,38-42]$} \\
\hline Bilberry & AOM/DSS mouse & $\begin{array}{l}\text { Decreased tumor number and } \\
\text { inflammation }\end{array}$ & [43] \\
\hline Bilberry extract & AOM rat & $\begin{array}{l}\text { Reduced total ACF, colonic cellular } \\
\text { proliferation, and COX-2 mRNA } \\
\text { expression }\end{array}$ & [44] \\
\hline Cranberry & $\begin{array}{l}\text { HT-29, HCT116, SW480, and } \\
\text { SW620 cells }\end{array}$ & $\begin{array}{l}\text { Inhibited cell growth; promoted } \\
\text { apoptosis }\end{array}$ & {$[33,45]$} \\
\hline Chokeberry & HT-29 and Caco-2 cells & $\begin{array}{l}\text { Inhibited cell growth; arrested G1/G0 } \\
\text { and G2/M phases; increased expression } \\
\text { of p21WAF1 and p27KIP1; decreased } \\
\text { expression of cyclin A and cyclin B }\end{array}$ & {$[38,40,46,48,49]$} \\
\hline Chokeberry & AOM rat & $\begin{array}{l}\text { Reduced total ACF and colonic cellular } \\
\text { proliferation }\end{array}$ & [44] \\
\hline Blackberry & $\begin{array}{l}\text { HT-29, HCT116, and CaCo-2 } \\
\text { cells }\end{array}$ & $\begin{array}{l}\text { Inhibited cell growth; promoted } \\
\text { apoptosis; suppressed IL-12 release; } \\
\text { suppressed peroxyl radical-induced } \\
\text { cellular oxidative damage and apoptosis }\end{array}$ & {$[33,50,51]$} \\
\hline $\begin{array}{l}\text { Red raspberry and strawberry } \\
\text { extract, lingonberry, } \\
\text { elderberry, black currant }\end{array}$ & HT-29 and HCT116 cells & $\begin{array}{l}\text { Inhibited cell growth; promoted } \\
\text { apoptosis }\end{array}$ & {$[33,39,40]$} \\
\hline Prunus spinosa drupes & HCT 116 cell, xenograft mouse & $\begin{array}{l}\text { Inhibited growth and colony formation; } \\
\text { promoted apoptosis in cells; reduced } \\
\text { tumor growth in xenograft mice }\end{array}$ & [53] \\
\hline Grapes & $\begin{array}{l}\text { HT-29, CaCo-2, and HCT-116 } \\
\text { cells }\end{array}$ & $\begin{array}{l}\text { Inhibited cell growth; promoted } \\
\text { apoptosis; suppressed the activity of } \\
\text { topoisomerase I; suppressed } \\
\text { strand-breaking effects; decreased } \\
\text { expression of anti-apoptotic proteins } \\
\text { survivin, cIAP-2, XIAP; arrested cells in } \\
\text { G1; inhibited tyrosine kinase }\end{array}$ & {$[38,42,54-56]$} \\
\hline Grape extract & AOM rat & $\begin{array}{l}\text { Reduced total ACF, COX-2 mRNA } \\
\text { expression }\end{array}$ & {$[44]$} \\
\hline Red grape & $\mathrm{APC}^{\mathrm{min}}$ mouse & $\begin{array}{l}\text { Decreased adenoma burden and } \\
\text { adenoma number; reduced the } \\
\text { expression of AKT and Ki-67 }\end{array}$ & [57] \\
\hline
\end{tabular}


Table 2. Cont.

\begin{tabular}{|c|c|c|c|}
\hline Source & Model & Finds & Ref. \\
\hline Red wine & HCT-15 and HCT-116 cells & $\begin{array}{l}\text { Suppressed cell growth; blocked S, G2, } \\
\text { and M phase; reduced cell proliferation; } \\
\text { increased p53 and p } 21\end{array}$ & {$[58,59]$} \\
\hline Tart cherry & APC-mouse & $\begin{array}{l}\text { Decreased weight loss and tumor burden } \\
\text { in combination with sulindac }\end{array}$ & {$[60]$} \\
\hline Illawarra plum & HT 29 cell & $\begin{array}{l}\text { Suppressed cell growth; arrested S cell } \\
\text { phase; increased apoptosis; decreased } \\
\text { telomerase activity and telomere length }\end{array}$ & {$[61]$} \\
\hline $\begin{array}{l}\text { Eugenia jambolana (Java } \\
\text { plum) }\end{array}$ & HCT 116 cell & $\begin{array}{l}\text { Suppressed cell proliferation; promoted } \\
\text { apoptosis; elevated colon cancer stem cell }\end{array}$ & {$[62]$} \\
\hline Vitis coignetiae & HT-29 and HCT- 116 cells & $\begin{array}{l}\text { Inhibited cell viability; induced apoptotic } \\
\text { cells; inhibited cell growth; activated } \\
\text { AMPK } \alpha 1 \text {; inhibited mechanistic target of } \\
\text { rapamycin (mTOR); inhibited invasive } \\
\text { cells; suppressed NFkB-MMP-2/MMP-9 } \\
\text { axis; inhibited cell migration, suppressed } \\
\text { transepithelial electrical resistance }\end{array}$ & [63-66] \\
\hline Vitis coignetiae Pulliat & Xenograft mouse & Inhibited tumor growth & [65] \\
\hline Purple potato & Colon cancer stem cell & $\begin{array}{l}\text { Suppressed proliferation; promoted } \\
\text { apoptosis; suppressed WNT signaling } \\
\text { pathway }\end{array}$ & [29] \\
\hline Purple fleshed sweet potato & WiDr and SW480 cells & $\begin{array}{l}\text { Inhibited cell growth; decreased cell } \\
\text { number; arrested G1 phase }\end{array}$ & {$[67,68]$} \\
\hline Sweet potato $\mathrm{p} 40$ & AOM mouse & $\begin{array}{l}\text { Decreased ACF number and cell } \\
\text { proliferation; promoted apoptosis }\end{array}$ & [67] \\
\hline Purple-shoot tea & HT-29 cell, COLO 320DM & $\begin{array}{l}\text { Inhibited cell proliferation; arrested } \\
\text { G0/G1 cell phase; promoted apoptosis; } \\
\text { reduced cyclin E and cyclin D1; } \\
\text { upregulated p21 and p27 } \\
\text { cyclin-dependent kinase inhibitors; } \\
\text { activated PAPR cleavage of caspase 3; } \\
\text { increased Bax/Bcl-2 ratio }\end{array}$ & [69] \\
\hline Curly kale & $\begin{array}{l}\text { Caco-2, HT-29, and HCT } 116 \\
\text { cells }\end{array}$ & Inhibited cell proliferation & [70] \\
\hline Pistacia atlantica sub kurdica & HT 29 cell & Inhibited cell growth; arrested S phase & [72] \\
\hline Chinese eggplant & HT 29 cell & $\begin{array}{l}\text { Antioxidant, protected cell from DNA } \\
\text { damage }\end{array}$ & [71] \\
\hline Apple & Rat & $\begin{array}{l}\text { Inhibited ACF, regulated } \\
\text { apoptosis-related genes Aurka, p53 and } \\
\text { COX-2, and cell migration-related genes } \\
\text { MMP-2 and } 9\end{array}$ & [73] \\
\hline
\end{tabular}

\subsubsection{Grapes}

Besides berries, grapes are of great interest for research due to their rich anthocyanin profiles and noted health benefits for humans. In HT-29 and CaCo-2 cells, the anthocyaninrich extracts from grapes could inhibit cell growth and promote apoptosis $[38,54,55]$. The grape extract has the potential to reduce the side effects of some chemotherapy drugs by suppressing the activity of topoisomerase I and the DNA strand breaks [42]. Compared to phenolic acids, tannins, and flavonol components, the grape anthocyanin extract showed the greatest antiproliferation effects. In another study, however, the authors found that the non-anthocyanin fraction showed a better antitumor effect [56]. In the AOM rat model, 
the grape extract reduced the total burden of ACF and COX-2 mRNA expression [44]. In APC ${ }^{\text {min }}$ mice, the grape pomace extract decreased adenoma burden, adenoma number, and the expression of AKT and Ki-67 [57].

\subsubsection{Red Wine}

Red wine contains anthocyanins as well as flavonoids and their derivatives and shows various promising biological effects. The methanol extracts of red wine could suppress HCT-15 cell growth and block the S, G2, and M phases [58]. The anthocyanin fraction showed higher efficiency than the non-anthocyanin fractions. In HCT-116 cells, the lyophilized red wine extract reduced cell proliferation, increased the expression of p53, p21 cell cycle gatekeepers, induced antioxidant response by activating transcriptional factor, nuclear factor erythroid 2-related factor 2 (Nrf2), and promoted differentiation through E-cadherin and the epithelial-mesenchymal transition (EMT) pathway [59].

\subsubsection{Tart Cherry}

Similar to whole tart cherry, anthocyanin-rich extract from tart cherry could decrease bodyweight loss and tumor burden when combined with sulindac in APC ${ }^{\mathrm{min}}$ mice [60].

\subsubsection{Plum}

Polyphenol-rich extract from Illawarra plum (Podocarpus elatus Endl.) suppressed cell growth, arrested $S$ cell phase, increased apoptosis, and decreased telomerase activity and telomere length in HT-29 cells [61]. The anthocyanin extract from Java plum (Eugenia jambolana) suppressed cell proliferation, promoted apoptosis in HCT-116 cells, and elevated the proportion of colon cancer stem cells [62].

\subsubsection{Vitis coignetiae Pulliat}

Grape family fruit Vitis coignetiae Pulliat (Meoru in Korean) has been used in Korean folk medicine to treat inflammatory disorders and cancer for a long time. The intense dark red hue of Vitis coignetiae Pulliat indicates an abundance of anthocyanin pigments [63]. Anthocyanins isolated from Meoru inhibited cell viability, proliferation, motility, and invasiveness, and induced cell apoptosis in HCT-116 and HT-29 cells [63-66]. In the HT-29 xenograft mouse model, the anthocyanins isolated from Meoru significantly suppressed tumor growth [65].

\subsubsection{Purple Fleshed Sweet Potato}

Purple fleshed sweet potato is a specific sweet potato rich in anthocyanins [67]. The anthocyanin extract from purple fleshed sweet potato decreased cell number, inhibited cell growth, and promoted cell cycle arrest in WiDr and SW480 cells [67,68]. In colon cancer stem cells, anthocyanin extraction suppressed proliferation, promoted apoptosis, and suppressed the WNT signaling pathway [29]. In the mouse model of AOM-induced $\mathrm{CRC}$, anthocyanin extraction decreased the ACF number, cell proliferation, and promoted apoptosis [67].

\subsubsection{Other Fruits and Vegetables}

The anthocyanin extract from purple-shoot tea [69], curly kale [70], Chinese eggplant [71], and Pistacia atlantica sub kurdica [72], and apple [73] showed antitumor effects in cell lines or carcinogenesis animal models. The antitumor effects are associated with cell proliferation inhibition, apoptosis induction, cell migration inhibition, cell cycle arrest, DNA damage protection, and antioxidation.

\subsection{Anthocyanin Single Compounds and Their Metabolites in Colon Cancer Prevention}

\subsubsection{Cyanidin}

Cyanidin is one of the most widespread anthocyanidins in fruits and vegetables. Aglycone cyanidin can inhibit CRC cell growth and proliferation [74-76]. In Cvorovic's 
study, they found that the cell toxicity was higher in drug-resistant cancer cells than that in their parental cells [76]. In Briviba's study, the author found that aglycone cyanidin showed better effects than its glycosides, cyanidin chloride-3-5-diglucoside and cyanidin chloride-3galactoside [75]. In the study by Renis, they reported that cyanidin-3-O- $\beta$-glucopyranoside can inhibit cancer cell growth and proliferation with different molecular effects than the aglycone cyanidin [74].

The purified cyanidin-3-glucoside from strawberries showed antioxidant effects as well as the ability to inhibit the cell growth of HT-29 and HT-116 cells. Moreover, cyanidin3-glucoside had the best antioxidant effects among the anthocyanins and other phenolics extracted from strawberries [77]. The cyanidin-3-glucoside single component promoted colon cancer cell attachment to fibronectin and inhibited 3D spheroid growth [78]. Cyanidin-3-O$\beta$-glucoside extracted from purple corn can decrease the development of colonic mucosal lesions and ACF induction in DMH-PhIP-treated animals [79]. Cyanidin 3-cyanidin 2" $O$ - $\beta$-D-glucopyranosyl- $6^{\prime \prime}-O-\alpha$-rhamnopyransyl- $\beta$-D - glucopyranoside and 3-cyanidin $6^{\prime \prime}-O-\alpha$-L-rhamnopyranosyl- $\beta$-D-glucopyranoside isolated from tart cherry decreased the number and volume of adenomas in APC ${ }^{\mathrm{min}}$ mice, and reduced the cell growth of the HT-29 and HCT-116 cells [31].

\subsubsection{Delphinidin}

Compared to cyanidin, delphinidin differs in the number and position of hydroxyl groups on the $b$ ring in the molecular structure. Delphinidin inhibited cell growth, decreased cell viability, arrested the G1 and G2/M cell phases, and promoted apoptosis in the Caco-1 and HCT-116 cells [80-82]. The cell toxicity of delphinidin is higher in drug-resistant cancer cells than that in their mother cells [76].

\subsubsection{Pelargonidin}

Pelargonidin, pelargonidin-3-glucoside, and pelargonidin-3-rutinoside isolated from strawberries can inhibit the cell growth of HT-29 and HCT-116 cells [77]. Pelargonidin, but not pelargonidin-3-glucoside or pelargonidin-3-rutinoside, has the best antioxidant efficiency.

\subsubsection{Metabolites}

Gut anthocyanin metabolites, gallic acid, 3-O-methylgallic acid, and 2,4,6-trihydroxy benzaldehyde reduce cell proliferation more effectively than anthocyanins in Caco-2 cells [83]. In addition, gallic acid and 3-O-methylgallic acid decreased cell viability, arrested G0/G1 cell cycle, promoted apoptosis, and caused DNA fragmentation and nuclear condensation $[84,85]$. The effects of single anthocyanin components and their metabolites in cancer prevention of CRC are summarized in Table 3.

Table 3. Anthocyanin or a single compound in colon cancer prevention.

\begin{tabular}{|c|c|c|c|c|}
\hline Anthocyanins & Source & Model & Finds & Ref. \\
\hline \multicolumn{5}{|l|}{ Cyanidin } \\
\hline $\begin{array}{l}\text { Cyanidin chloride } \\
\text { Cyanidin } \\
\text { chloride-3-5-diglucoside } \\
\text { Cyanidin chloride-3 } \\
\text { galactoside }\end{array}$ & & HT29 cells & $\begin{array}{l}\text { Inhibited the neurotensin- and } \\
\text { EGF-induced increased rate of } \\
\text { extracellular acidification; } \\
\text { inhibited intracellular } \mathrm{Ca}^{2+} \\
\text { concentration induced by neurotensin }\end{array}$ & [75] \\
\hline $\begin{array}{l}\text { Cyanidin-3-O-b } \\
\text { glucopyranoside }\end{array}$ & & & $\begin{array}{l}\text { Inhibited cell growth and proliferation; } \\
\text { increased } \\
\text { ATM, topoisomerase II, HSP70 and p53 } \\
\text { expression; increased DNA damage } \\
\text { ROS-independent }\end{array}$ & [74] \\
\hline
\end{tabular}


Table 3. Cont.

\begin{tabular}{|c|c|c|c|c|}
\hline Anthocyanins & Source & Model & Finds & Ref. \\
\hline Cyanidin & & $\begin{array}{l}\text { Caco-2,LoVo and } \\
\text { LoVo/ADR (metastatic } \\
\text { colon cancer cells) }\end{array}$ & $\begin{array}{l}\text { Had cytotoxicity in metastatic cells, } \\
\text { especially sensitive to drug-resistant } \\
\text { LoVo/ADR }\end{array}$ & [76] \\
\hline Cyanidin-3-glucoside & Strawberries & $\begin{array}{l}\text { HT29 and HCT-116 } \\
\text { cells }\end{array}$ & $\begin{array}{l}\text { Anthocyanin extract had better } \\
\text { antiproliferation effects on the cancer } \\
\text { cells. Pure anthocyanin compounds } \\
\text { differed in their efficacy on cell } \\
\text { proliferation }\end{array}$ & [77] \\
\hline Cyanidin-3-glucoside & & $\begin{array}{l}\text { HCT116, Caco2, and } \\
\text { SW480 cells }\end{array}$ & $\begin{array}{l}\text { Regulated the interaction of talin with } \\
\beta 1 \text { A-integrin; promoted the attachment } \\
\text { between colon cancer cells and } \\
\text { fibronectin; inhibited 3D spheroid } \\
\text { growth }\end{array}$ & [78] \\
\hline Cyanidin-3-O- $\beta$-glucoside & Purple corn & DMH-PhIP rat & $\begin{array}{l}\text { Decreased the development of colonic } \\
\text { mucosal lesions and ACF induction }\end{array}$ & [79] \\
\hline
\end{tabular}

Cyanidin

3-cyanidin

$2^{\prime \prime}-O-\beta$-D-glucopyranosyl-

$6^{\prime \prime}-O-\alpha$-rhamnopyransyl- $\beta$ -

APC-mouse

D-glucopyranoside

HT-29 and HCT-116

Decreased the number and volume of cells

$6^{\prime \prime}-O-\alpha$-L-rhamnopyranosyl-

$\beta$-D-glucopyranoside

\section{Pelargonidin}

\begin{tabular}{|c|c|c|}
\hline $\begin{array}{l}\text { Cyanidin-3-glucoside } \\
\text { Pelargonidin } \\
\text { Pelargonidin-3-glucoside }\end{array}$ & Strawberries & $\begin{array}{l}\text { HT-29 and HCT-116 } \\
\text { cells }\end{array}$ \\
\hline
\end{tabular}

Anthocyanin extract had better antiproliferation effects on cancer cells. Pure anthocyanin compounds differed in their efficacy cell proliferation

\begin{tabular}{ll}
\hline Delphinidin & \\
\hline Delphinidin & CaCo-2 cell \\
\hline Delphinidin & HCT-116 cell \\
\hline Cyanidin and delphinidin & $\begin{array}{l}\text { Caco-2, LoVo and } \\
\text { LoVo/ADR cells }\end{array}$
\end{tabular}

\section{Metabolites}

Anthocyanin metabolites gallic acid, 3-O-methylgallic acid, syringic acid, protocatechuic acid, vanillic acid, and 2,4,6trihydroxybenzaldehyde

Malvidin-3-glucoside
Anthocyains metabolites
gallic acid, 3-O-methylgallic
acid, and 2,4,6-
trihydroxybenzaldehyde

Anthocyanins digested in in-vitro GI model

Purple-fleshed sweet potato
Anthocyanin metabolites gallic acid, 3-O-methylgallic acid, and 2,4,6 trihydroxybenzaldehyde reduce cell proliferation in Caco- 2 cells more effectively than anthocyanins.

Anthocyanin metabolites gallic acid and 3-O-methylgallic acid decreased cell viability; arrested G0/G1 phase; promoted apoptosis; caused DNA fragmentation and nuclear condensation

Anthocyanin profile changed significantly after GI digestion 


\section{Molecular Mechanisms Associated with Chemopreventative Effects of Anthocyanins in Colon Cancer}

\subsection{Antioxidant}

The most well-known mechanism associated with the health-protective effects of anthocyanins is antioxidant activity. Oxidative stress is a complex condition involving reactive oxygen species (ROS) $\left(\mathrm{ONOO}^{-}, \mathrm{O}^{2-}, \mathrm{H}_{2} \mathrm{O}_{2}\right.$, and LPO) and antioxidants (GPx and $\mathrm{SOD}_{2}$ ). Oxidative stress occurs as a response to increased ROS or decreased antioxidants, leading to a failure to prevent ROS-induced oxidative damage [86]. Anthocyanins are reported to have superior antioxidant properties compared with other related polyphenols and well-recognized antioxidants such as ascorbic acid and $\alpha$-tocopherol $[77,87]$. Anthocyanins were reported to suppress oxidative damage, DNA strand-breaking effects, transepithelial electrical resistance in colon cancer cells, and decreased oxidative stress marker urinary 8-OHdG levels in animal models of AOM-induced CRC [27,35,42,47,51,63,71,76,81,86,88].

Anthocyanins are antioxidative by scavenging ROS, promoting glutathione reductase expression involved in metal chelation, inhibiting lipoprotein oxidation, inhibiting peroxyl radical-induced apoptosis, and protecting the formation of oxidative DNA damage $[47,51,71,76,86,88]$. The antioxidant capacity of anthocyanins is affected by their structures. Hydroxyl groups in position 3 of ring $C$ and the $3^{\prime}, 4^{\prime}$ and $5^{\prime}$ positions in ring $B$ are the major components responsible for the antioxidant activity. Generally, cyanidin with groups $3^{\prime}, 4^{\prime}$ di-OH substituted has higher antioxidant activity when compared to pelargonidin, malvidin, and peonidin with a single $\mathrm{OH}$ group in ring $\mathrm{B}$ [89]. However, delphinidin still has low antioxidant activity even with groups $3^{\prime}$ and $4^{\prime}$ di-OH substituted. Types of glycosylation of anthocyanidins are also important for their antioxidant activities. Different glycosylation patterns either enhanced or reduced the antioxidant capacity [71]. In addition, the antioxidant capacity of anthocyanins is impacted by the food intake of anthocyanins.

The critical molecules involved in antioxidation include the PI3K/AKT signaling pathway, NFKB/mitogen-activated protein kinase (MAPK) signaling pathway, Nrf2, p27, HSP70, and 8-oxoguanine DNA glycosylase-1 (OGG1) [59,74,86,90]. The molecular mechanisms associated with antioxidation differ among anthocyanins. For example, the decreased ROS caused by cyanidin chloride is due to the upregulation of HSP70. Cyanidin-3-O- $\beta$ glucopyranoside not only dose-dependently modulated ROS level, but also decreased DNA fragmentation by non-dose-dependently regulating HSP70 [74]. However, anthocyanins might prevent colon carcinogenesis through multiple biological processes aside from antioxidation.

\subsection{Antiproliferation}

Anthocyanin-rich whole foods, anthocyanin extracts, anthocyanin single compounds, and anthocyanin metabolites have all exhibited antiproliferation activities in multiple colon cancer cell types and animal models. In parallel with the antiproliferation effects, anthocyanins arrested the cell cycle at G1/G0 and G2/M, and modulated cell cycle-related genes (cyclin A, cyclin B, cyclin E, cyclinD1, p21, p25, p53, and cyclin-dependent kinase inhibitors) $[46,58,61,80,81]$. The MAPK pathway (ERK, c-Jun-NH2 kinase, and p38) represents a superfamily of proteins that regulate cell differentiation, proliferation, and survival during carcinogenesis [16]. Blocking activation of the MAPK pathway was reported as one of the molecular mechanisms for the anticarcinogenic action of anthocyanidins in colon cancer $[16,63,64,91]$. Inhibition of the receptor tyrosine kinases (RTKs) such as epidermal growth factor receptor (EGFR), ErbB2, ErbB3, vascular endothelial growth factor receptor-2 (VEGFR-2), VEGFR-3, and insulin-like growth factor 1 receptor (IGF1R) might be another molecular event associated with the antiproliferation effects of anthocyanins in cancers [92,93]. Cyanidin-3-Oglucoside and delphinidin-3-O-glucoside significantly inhibited EGFR in HCT-116 and HT-29 cells [55]. AKT/ERK/NFKB signaling cascades play an important role in cell proliferation and survival [5]. Lyophilized acai pulp increased the negative regulators of cell proliferation such as Dlc1 and AKT3 [26]. Pomegranate juice 
inhibited the phosphorylation of PI3K/AKT and mTOR expression and suppressed NFkB in the AOM rat model [28]. Lyophilized strawberries decreased PI3K/AKT signaling and NFkB in the AOM/DSS mouse model [16]. Grape anthocyanin extract from red grape (Vitis coignetiae Pulliat) has inhibitory effects on PI3K/AKT and mTOR [57,63,65]. A decrease in both hTERT expression and telomere length was reported as one of the mechanisms of the antitumor effects of Illawarra plum in colon cancer [61].

The antiproliferation effects of anthocyanins are also affected by their structures. The ortho-dihydroxyphenyl structure on the B-ring was considered as the functional group contributing to the inhibitory action [94]. The nonacylated monoglycosylated anthocyanins have higher effects than anthocyanins with pelargonidin, triglycoside, and/or acylation with cinnamic acid exerted [40,71]. For each anthocyanin, the exact mechanisms for these potential anticancer activities differ from one another.

\subsection{Induction of Apoptosis}

Apoptosis is another key target for antitumor activities. Anthocyanin-rich whole foods, anthocyanin extract, anthocyanin single compounds and anthocyanin metabolites have all exhibited apoptosis-inducing activities in multiple colon cancer cell types and animal models. The pro-apoptotic effect of anthocyanins can be attributed to the ROS-mediated mitochondrial caspase-independent pathway $[62,82,88]$. Anthocyanin extract from purpleshoot tea promoted apoptosis through cleavage of poly adenosine diphosphate-ribose polymerase (PARP), activation of caspase 3, and an increased expression of the Bax/Bcl-2 ratio [69]. Anthocyanin extracts and single compounds promoted apoptosis by decreasing the expression of anti-apoptotic proteins (survivin, cIAP-2, and XIAP) [55]. Anthocyanins could promote apoptosis in a p53-independent manner in colon cancer stem cells by elevating Bax and cytochrome c, proteins-mediating mitochondrial apoptosis [29,82].

\subsection{Anti-Invasive Activity}

Cancer cells can spread beyond the layer of tissue where the initial tumor developed and grow into nearby healthy tissues. Anthocyanin extract from Vitis coignetiae Pulliat inhibited HT-29 cell invasion by suppressing the PI3K/AKT pathway and NFkB-MMP2/MMP-9 axis $[64,66]$. The EMT broadly regulates cancer cell invasion and metastasis. Anthocyanin extract from grapes can induce morphological change, increase the epithelial marker Ecadherin, and reduce the cell migration activity in HCT-116 cells [59]. Cancer stem cells (CSCs) are a subpopulation of cancer cells with unique properties of self-renewal, infinite division, and multi-directional differentiation potential [95]. CSCs play critical roles in colon cancer invasion and metastasis. Anthocyanin extract from grapes can significantly decrease the expression of colon CSCs markers CD44 and CD133 [59]. Anthocyanins extracted from baked purple-fleshed potato and Eugenia jambolana can inhibit proliferation and promote apoptosis in both colon cancer cells and colon CSCs [29,62]. The suppression of $\beta$-catenin, the WNT pathway effector and the key regulator of CSCs proliferation, contributed to the inhibition of CSCs by anthocyanins. $\beta$-catenin and E-cadherin regulation were also found in CRC patients consuming BRB powder [96].

\subsection{Gene Demethylation}

BRB anthocyanins decreased the expression of DNA methyltransferase and demethylated the hypermethylated promoters of the secreted frizzled-related protein 2 (SFRP2) gene to induce colon cancer carcinogenesis in the AOM-DSS mouse model [5]. In CRC patients, dietary BRB decreased the methylation of tumor suppressor genes, SFRP2, paired box 6a (PAX6a), Wnt inhibitory factor 1 (WIF1) [96]. In colon cancer cell lines, anthocyanin extract from BRB suppressed the activity and protein expression of DNA methyltransferase enzymes, DNMT1 and DNMT3B, and demethylated WNT upstream regulators, CDKN2A, SFRP2, SFRP5, and WIF1 [32]. 


\subsection{Anti-Inflammation}

Chronic inflammation induces oncogenic mutations, genomic instability, immune microenvironment changes, early tumor promotion, angiogenesis, and increased risk of CRC [5]. Reduction in inflammation by anti-inflammatory pharmaceuticals such as NSAIDs and 5-aminosalicylate showed chemopreventive effects for CRC. Anthocyanin-rich whole foods showed anti-inflammatory effects in multiple animal models.

Lyophilized strawberries reduced proinflammatory mediators, tumor necrosis factor$\alpha($ TNF- $\alpha)$, IL-1 $\beta$, IL-6, and nitrosative stress [16]. Bilberry anthocyanin-rich extract decreased the colon length in AOM/DSS mice $[43,44]$. Cytokine GM-CSF and IL-8 were also found to be decreased by BRB powder in patients with CRC [32]. Anthocyanins were also shown to directly regulate cytokine and immune effectors. Blackberry extract suppressed lipid A-induced interleukin-12 released from mouse bone marrow-derived dendritic cells [50]. Single anthocyanins, cyanidin-3-rutinoside and quercetin-3-rutinoside, inhibited myeloid-derived suppressor cell (MDSC) expansion and modulated T lymphocyte proliferation [97]. NFKB regulates multiple genes that drive inflammatory responses including COX-2 and iNOS, which can promote the development of CRC [16]. Pomegranate juice decreased expression of COX-2, iNOS, NF- $\mathrm{kB}$ (p65), and VCAM-1 in AOM-treated rats [28]. Lyophilized strawberries inhibited the PI3K/AKT and NF-KB signaling pathway in tandem with a reduction in proinflammatory mediators and nitrosative stress [16]. Bilberry and grape anthocyanin extract can decrease mRNA expression of COX-2 in AOMtreated rats [44]. Delphinidin-3-O-glucoside, cyanidin-3-O-glucoside, delphinidin (DC) and gallic acid (GA) decreased the immune checkpoint, programmed cell death protein-1 (PD-1) and programmed death-ligand-1 (PD-L1), in HCT-116 and HT-29 cells, and thus showed the potential to activate the immune response in the tumor microenvironment and induce cancer cell death [98]. Although the anti-inflammatory effects of anthocyanins are broadly reported, the details on CRC prevention are limited. The role of anthocyanins in inflammation and immune effectors remains a challenging area of research.

\subsection{Microbiota}

Alterations in the composition and function of bacterial microbiota are considered significant factors for developing inflammation-promoted CRC [5]. The colon is the major place for anthocyanin metabolism due to microbial metabolism [11,14]. Anthocyanins showed both bacteriostatic and bactericidal activities in vitro [99]. Therefore, investigations on anthocyanins and microbiota play critical roles in elucidating the health benefits of anthocyanins as they relate to colon cancer. A cross-sectional study showed that the higher intake of anthocyanin-rich food was associated with higher microbial diversity [100]. Diets containing the anthocyanin extract from blackberries and strawberries significantly suppressed the populations of the pro-inflammatory Bilophila wadsworthia in AOM/DSS-treated animals [25]. Diets containing BRB modulate the imbalance in gut microbiota during carcinogenesis by decreasing the pathogenic bacteria Desulfovibrio sp. and Enterococcus spp., and increasing probiotics Eubacterium rectale, Faecalibacterium prausnitzii, and Lactobacillus in AOM/DSS-induced inflammation-associated CRC [34]. In the colitis mouse model, anthocyanins can reverse the DSS-induced reduction in Porphyromonadaceae, Rikenellaceae Prevotellaceae, Firmicutes/Bacteroidetes ratio, and decrease Ruminococcus gnavus [101,102]. The beneficial microbiota activities of anthocyanins are frequently reported in multiple disease animal models and human clinical trials. In C57BL/6 mice, blueberry anthocyanin extract increased Bifidobacterium, Lactobacillus, Roseburia, Faecalibaculum, and Parabacteroides [103]. In the mouse model, bileberry anthocyanins reduced the ratio of Firmicutes/Bacteroidetes (F/B), and increased Akkermansia and Parabacteroides [104]. In human clinical trials, anthocyanin-rich apple products increased Sutterella, Butyricicoccus, and Lactobacillus and reduced Streptococcus, Ruminococcus, Blautia, and Roseburia [105]. More research is needed to better understand how anthocyanins modulate the gut microbiota and thus regulate their bioavailabilities and antitumor activities. 


\section{Future Directions in Anthocyanin Application \\ 4.1. Encapsulation}

The low bioavailability of anthocyanins is a pitfall for clinical applications. Encapsulation of anthocyanins or their bioactive metabolites has the potential to increase the localized concentration and boost their health benefits such as chemoprevention for CRC. Anthocyanin nanocomplexes with chitosan hydrochloride (CHC), carboxymethyl chitosan (CMC), and beta-Lactoglobulin (beta- $\mathrm{Lg}$ ) can significantly improve the stability and bioavailability of anthocyanins in a simulated gastrointestinal tract [106]. Oidtmann's study also showed that encapsulation can inhibit the early degradation of anthocyanins in the intestinal system [107]. The biological properties, especially the antioxidant effects, of bilberry extract-loaded pectin amide core-shell capsules, whey protein matrix capsules, and coated apple pectin matrix capsules were comparable to those of the non-encapsulated bilberry extract [108]. In colon cancer cell line HT-29, anthocyanins encapsulated within the FA-g-MD wall showed higher antioxidant activities than anthocyanins alone [109]. Endogenous nanoparticle exosomes can be used to encapsulate anthocyanins in order to increase their availability and efficiency. In Aqil's study, milk exosome-encapsulated anthocyanins had higher antiproliferation efficacy in ovarian cancer cell lines [110]. Moreover, encapsulation may have the possibility of regulating the gut microbial composition, and the biosynthesis of short-chain fatty acids by the gut microbiota [111].

\subsection{Combination}

The antitumor activity of anthocyanins can be affected by their structures. Methylation by catechol-O-methyltransferase (COMT) during metabolism will decrease the efficiency of anthocyanins [112]. The antiproliferative activity of anthocyanins extracted from grape anthocyanins, cyanidin-3-glucoside and delphinidin-3-glucoside, was improved when used in combination with the drug Entacapone, a COMT inhibitor [113]. The improved efficacy may be due to the higher bioavailability by inhibition of COMT and an increase in ROS.

To counteract their low bioavailability, anthocyanins can be combined with different anthocyanins, other polyphenols, and chemotherapy drugs [114,115]. Luteolin is a common plant flavonoid with the potential for cancer prevention and treatment. The combination of cyanidin-3-O-glucoside chloride and luteolin had higher efficiency of antiproliferation and apoptosis induction than either compound on its own [116]. The binding of pectin to anthocyanins can improve the stability of anthocyanins to enhance their colonic accessibility and gut microbial fermentation [117]. When combined with chemotherapy drugs, anthocyanins had the potential to decrease their side effects and improve efficacy. In the APC ${ }^{\text {in }}$ mouse model, anthocyanin-rich tart cherry extract combined with sulindac had less significant body weight loss, fewer tumors, and a smaller total tumor burden [60]. Delphinidin showed the activity of autophagy induction in hepatocellular carcinoma cells. When delphinidin was combined with an inhibitor of autophagy, 3-methyladenine, the macroautophagy was significantly magnified [118]. Petunidin-3-O-glucoside combined with a PI3K inhibitor significantly increased cell death in glioblastoma cells [119]. Delphinidin selectively sensitized leukemia cell NB4 to As(III) by decreasing intracellular arsenic accumulation and strengthening intrinsic/extrinsic pathway-mediated apoptosis induction $[120,121]$.

\subsection{Gut Microbiota Fermentation}

Low bioavailability and complex metabolite profiles suggest that metabolites play an important role in the chemopreventive effects of anthocyanins. Gut microbiota is crucial in anthocyanin metabolism, as gut microbiota fermentation can help to formulate active metabolites of anthocyanins with antitumor activities. The metabolites produced by fermentation varies by the composition of microbiota and the chemical structure of anthocyanins [122]. New phenolic compounds such as syringic acid, rhamnetin, hippuric acid, cinammic acid, protocatechuic acid, caffeic acid, kaempferolrhamnoside, chlorogenic 
acid, cryptochlorogenic acid, ferulic acid, etc., are commonly found as the metabolites of anthoycanins after gut microbiota fermentation. Interestingly, some disparities in the metabolite profile of anthocyanins by different gut microbial strains were also noticed [123]. The alternation in gut microbiota and the bioavailability of anthoycanins by microbiota are two key elements in investigating the health benefits of anthocyanins. However, because collective knowledge of the gut microbiome still necessitates expansion, further research is needed to determine the association between the health benefits of anthocyanins and microbiota fermentation.

\section{Conclusions}

Epidemiology evidence, cell line investigations, and animal preclinical studies all showed the antitumor effects of anthocyanins in colon cancer. Anthocyanin-rich whole foods, anthocyanin extracts, anthocyanin single compounds, and the metabolites of anthocyanins all exhibited antitumor effects against CRC. The antitumor effects of anthocyanins are associated with multiple biological processes including proliferation, apoptosis, cell invasion, methylation, inflammation, and gut microbiota modification involving multiple genes and signaling pathways. The antitumor effects of anthocyanins are affected by their structures. Low bioavailability is a large pitfall in the research on anthocyanins. Phase I and phase II metabolites, conjugated products, and microbe-generated metabolites should be considered in the total bioavailability. The antitumor effects of anthocyanins may be attributed to the involvement of multiple genes, integrated roles in cell proliferation, apoptosis, invasion and metastasis, epigenetics, inflammation and gut microbiota modification. Using encapsulation strategies can increase the local bioavailability and target tissue specificity. Combining different anthocyanins, and anthocyanins with other polyphenols or drugs, and harnessing the gut microbiota fermentation, may enhance the health benefits of anthocyanins.

Author Contributions: N.S. conceptualized the idea, drafted, and reviewed the manuscript. X.C. reviewed the manuscript and revised the manuscript. T.C. conceptualized the idea, supervised the project, reviewed, and revised the manuscript. All authors have read and agreed to the published version of the manuscript.

Funding: This work is supported by the internal funds of The Ohio State University Comprehensive Cancer Center.

Acknowledgments: We thank Kamila Jaroniec for the manuscript editing.

Conflicts of Interest: The authors declare no conflict of interest.

\section{References}

1. Bray, F.; Ferlay, J.; Soerjomataram, I.; Siegel, R.L.; Torre, L.A.; Jemal, A. Global cancer statistics 2018: GLOBOCAN estimates of incidence and mortality worldwide for 36 cancers in 185 countries. CA Cancer J. Clin. 2018, 68, 394-424. [CrossRef]

2. Birt, D.F.; Phillips, G.J. Diet, genes, and microbes: Complexities of colon cancer prevention. Toxicol. Pathol. 2014, 42, 182-188. [CrossRef]

3. Key, T.J. Fruit and vegetables and cancer risk. Br. J. Cancer 2011, 104, 6-11. [CrossRef]

4. Baby, B.; Antony, P.; Vijayan, R. Antioxidant and anticancer properties of berries. Crit. Rev. Food. Sci. Nutr. 2018, 58, 2491-2507. [CrossRef] [PubMed]

5. Chen, T.; Shi, N.; Afzali, A. Chemopreventive Effects of Strawberry and Black Raspberry on Colorectal Cancer in Inflammatory Bowel Disease. Nutrients 2019, 11, 1261-1281. [CrossRef]

6. Galvano, F.; Salamone, F.; Nicolosi, A.; Vitaglione, P. Anthocyanins-based drugs for colon cancer treatment: The nutritionist's point of view. Cancer Chemother. Pharmacol. 2009, 64, 431-432. [CrossRef]

7. Khoo, H.E.; Azlan, A.; Tang, S.T.; Lim, S.M. Anthocyanidins and anthocyanins: Colored pigments as food, pharmaceutical ingredients, and the potential health benefits. Food Nutr. Res. 2017, 61, 1361779. [CrossRef]

8. Fang, J. Bioavailability of anthocyanins. Drug Metab. Rev. 2014, 46, 508-520. [CrossRef]

9. Mallery, S.R.; Budendorf, D.E.; Larsen, M.P.; Pei, P.; Tong, M.; Holpuch, A.S.; Larsen, P.E.; Stoner, G.D.; Fields, H.W.; Chan, K.K.; et al. Effects of human oral mucosal tissue, saliva, and oral microflora on intraoral metabolism and bioactivation of black raspberry anthocyanins. Cancer Prev. Res. 2011, 4, 1209-1221. [CrossRef] 
10. Passamonti, S.; Terdoslavich, M.; Franca, R.; Vanzo, A.; Tramer, F.; Braidot, E.; Petrussa, E.; Vianello, A. Bioavailability of flavonoids: A review of their membrane transport and the function of bilitranslocase in animal and plant organisms. Curr. Drug Metab. 2009, 10, 369-394. [CrossRef]

11. Fernandes, I.; Faria, A.; Calhau, C.; de Freitas, V.; Mateus, N. Bioavailability of anthocyanins and derivatives. J. Funct. Foods 2014, 7, 54-66. [CrossRef]

12. Lila, M.A.; Burton-Freeman, B.; Grace, M.; Kalt, W. Unraveling Anthocyanin Bioavailability for Human Health. Annu. Rev. Food Sci. Technol. 2016, 7, 375-393. [CrossRef]

13. Kay, C.D. Aspects of anthocyanin absorption, metabolism and pharmacokinetics in humans. Nutr. Res. Rev. 2006, 19, 137-146. [CrossRef]

14. Woodward, G.M.; Needs, P.W.; Kay, C.D. Anthocyanin-derived phenolic acids form glucuronides following simulated gastrointestinal digestion and microsomal glucuronidation. Mol. Nutr. Food Res. 2011, 55, 378-386. [CrossRef]

15. Fang, J. Some anthocyanins could be efficiently absorbed across the gastrointestinal mucosa: Extensive presystemic metabolism reduces apparent bioavailability. J. Agric. Food Chem. 2014, 62, 3904-3911. [CrossRef]

16. Shi, N.; Clinton, S.K.; Liu, Z.; Wang, Y.; Riedl, K.M.; Schwartz, S.J.; Zhang, X.; Pan, Z.; Chen, T. Strawberry phytochemicals inhibit azoxymethane/dextran sodium sulfate-induced colorectal carcinogenesis in Crj: CD-1 mice. Nutrients 2015, 7, 1696-1715. [CrossRef]

17. Shi, N.; Riedl, K.M.; Schwartz, S.J.; Zhang, X.; Clinton, S.K.; Chen, T. Efficacy comparison of lyophilised black raspberries and combination of celecoxib and PBIT in prevention of carcinogen-induced oesophageal cancer in rats. J. Funct. Foods 2016, 27, 84-94. [CrossRef]

18. Rossi, M.; Negri, E.; Talamini, R.; Bosetti, C.; Parpinel, M.; Gnagnarella, P.; Franceschi, S.; Dal Maso, L.; Montella, M.; Giacosa, A.; et al. Flavonoids and colorectal cancer in Italy. Cancer Epidemiol. Biomark. Prev. 2006, 15, 1555-1558. [CrossRef]

19. Xu, M.; Chen, Y.M.; Huang, J.; Fang, Y.J.; Huang, W.Q.; Yan, B.; Lu, M.S.; Pan, Z.Z.; Zhang, C.X. Flavonoid intake from vegetables and fruits is inversely associated with colorectal cancer risk: A case-control study in China. Br. J. Nutr. 2016, 116, 1275-1287. [CrossRef]

20. Zamora-Ros, R.; Not, C.; Guino, E.; Lujan-Barroso, L.; Garcia, R.M.; Biondo, S.; Salazar, R.; Moreno, V. Association between habitual dietary flavonoid and lignan intake and colorectal cancer in a Spanish case-control study (the Bellvitge Colorectal Cancer Study). Cancer Causes Control 2013, 24, 549-557. [CrossRef]

21. Mursu, J.; Nurmi, T.; Tuomainen, T.P.; Salonen, J.T.; Pukkala, E.; Voutilainen, S. Intake of flavonoids and risk of cancer in Finnish men: The Kuopio Ischaemic Heart Disease Risk Factor Study. Int. J. Cancer 2008, 123, 660-663. [CrossRef]

22. Nimptsch, K.; Zhang, X.; Cassidy, A.; Song, M.; O’Reilly, E.J.; Lin, J.H.; Pischon, T.; Rimm, E.B.; Willett, W.C.; Fuchs, C.S.; et al. Habitual intake of flavonoid subclasses and risk of colorectal cancer in 2 large prospective cohorts. Am. J. Clin. Nutr. 2016, 103, 184-191. [CrossRef]

23. Zamora-Ros, R.; Barupal, D.K.; Rothwell, J.A.; Jenab, M.; Fedirko, V.; Romieu, I.; Aleksandrova, K.; Overvad, K.; Kyro, C.; Tjonneland, A.; et al. Dietary flavonoid intake and colorectal cancer risk in the European prospective investigation into cancer and nutrition (EPIC) cohort. Int. J. Cancer 2017, 140, 1836-1844. [CrossRef]

24. Wang, X.; Yang, D.Y.; Yang, L.Q.; Zhao, W.Z.; Cai, L.Y.; Shi, H.P. Anthocyanin Consumption and Risk of Colorectal Cancer: A Meta-Analysis of Observational Studies. J. Am. Coll. Nutr. 2019, 38, 470-477. [CrossRef]

25. Fernandez, J.; Garcia, L.; Monte, J.; Villar, C.J.; Lombo, F. Functional Anthocyanin-Rich Sausages Diminish Colorectal Cancer in an Animal Model and Reduce Pro-Inflammatory Bacteria in the Intestinal Microbiota. Genes 2018, 9, 133-150. [CrossRef]

26. Fragoso, M.F.; Romualdo, G.R.; Vanderveer, L.A.; Franco-Barraza, J.; Cukierman, E.; Clapper, M.L.; Carvalho, R.F.; Barbisan, L.F. Lyophilized acai pulp (Euterpe oleracea Mart) attenuates colitis-associated colon carcinogenesis while its main anthocyanin has the potential to affect the motility of colon cancer cells. Food Chem. Toxicol. 2018, 121, 237-245. [CrossRef]

27. Harris, G.K.; Gupta, A.; Nines, R.G.; Kresty, L.A.; Habib, S.G.; Frankel, W.L.; LaPerle, K.; Gallaher, D.D.; Schwartz, S.J.; Stoner, G.D. Effects of lyophilized black raspberries on azoxymethane-induced colon cancer and 8-hydroxy-2'-deoxyguanosine levels in the Fischer 344 rat. Nutr. Cancer 2001, 40, 125-133. [CrossRef]

28. Banerjee, N.; Kim, H.; Talcott, S.; Mertens-Talcott, S. Pomegranate polyphenolics suppressed azoxymethane-induced colorectal aberrant crypt foci and inflammation: Possible role of miR-126/VCAM-1 and miR-126/PI3K/AKT/mTOR. Carcinogenesis 2013, 34, 2814-2822. [CrossRef]

29. Charepalli, V.; Reddivari, L.; Radhakrishnan, S.; Vadde, R.; Agarwal, R.; Vanamala, J.K. Anthocyanin-containing purple-fleshed potatoes suppress colon tumorigenesis via elimination of colon cancer stem cells. J. Nutr. Biochem. 2015, 26, 1641-1649. [CrossRef]

30. Su, L.K.; Kinzler, K.W.; Vogelstein, B.; Preisinger, A.C.; Moser, A.R.; Luongo, C.; Gould, K.A.; Dove, W.F. Multiple intestinal neoplasia caused by a mutation in the murine homolog of the APC gene. Science 1992, 256, 668-670. [CrossRef]

31. Kang, S.Y.; Seeram, N.P.; Nair, M.G.; Bourquin, L.D. Tart cherry anthocyanins inhibit tumor development in Apc(Min) mice and reduce proliferation of human colon cancer cells. Cancer Lett. 2003, 194, 13-19. [CrossRef]

32. Wang, L.S.; Kuo, C.T.; Cho, S.J.; Seguin, C.; Siddiqui, J.; Stoner, K.; Weng, Y.I.; Huang, T.H.; Tichelaar, J.; Yearsley, M.; et al. Black raspberry-derived anthocyanins demethylate tumor suppressor genes through the inhibition of DNMT1 and DNMT3B in colon cancer cells. Nutr. Cancer 2013, 65, 118-125. [CrossRef] 
33. Seeram, N.P.; Adams, L.S.; Zhang, Y.; Lee, R.; Sand, D.; Scheuller, H.S.; Heber, D. Blackberry, black raspberry, blueberry, cranberry, red raspberry, and strawberry extracts inhibit growth and stimulate apoptosis of human cancer cells in vitro. J. Agric. Food Chem. 2006, 54, 9329-9339. [CrossRef]

34. Chen, L.; Jiang, B.; Zhong, C.; Guo, J.; Zhang, L.; Mu, T.; Zhang, Q.; Bi, X. Chemoprevention of colorectal cancer by black raspberry anthocyanins involved the modulation of gut microbiota and SFRP2 demethylation. Carcinogenesis 2018, 39, 471-481. [CrossRef]

35. Bornsek, S.M.; Ziberna, L.; Polak, T.; Vanzo, A.; Ulrih, N.P.; Abram, V.; Tramer, F.; Passamonti, S. Bilberry and blueberry anthocyanins act as powerful intracellular antioxidants in mammalian cells. Food Chem. 2012, 134, 1878-1884. [CrossRef]

36. Yi, W.; Fischer, J.; Krewer, G.; Akoh, C.C. Phenolic compounds from blueberries can inhibit colon cancer cell proliferation and induce apoptosis. J. Agric. Food Chem. 2005, 53, 7320-7329. [CrossRef]

37. Zu, X.Y.; Zhang, Z.Y.; Zhang, X.W.; Yoshioka, M.; Yang, Y.N.; Li, J. Anthocyanin extract ed from Chinese blueberry (Vaccinium uliginosum L.) and its anticancer effects on DLD-1 and COLO205 cells. Chin. Med. J. 2010, 123, 2714-2719.

38. Zhao, C.; Giusti, M.M.; Malik, M.; Moyer, M.P.; Magnuson, B.A. Effects of commercial anthocyanin-rich extracts on colonic cancer and nontumorigenic colonic cell growth. J. Agric. Food Chem. 2004, 52, 6122-6128. [CrossRef]

39. Wu, Q.K.; Koponen, J.M.; Mykkanen, H.M.; Torronen, A.R. Berry phenolic extracts modulate the expression of p21(WAF1) and Bax but not Bcl-2 in HT-29 colon cancer cells. J. Agric. Food Chem. 2007, 55, 1156-1163. [CrossRef]

40. Jing, P.; Bomser, J.A.; Schwartz, S.J.; He, J.; Magnuson, B.A.; Giusti, M.M. Structure-function relationships of anthocyanins from various anthocyanin-rich extracts on the inhibition of colon cancer cell growth. J. Agric. Food Chem. 2008, 56, 9391-9398. [CrossRef]

41. Jing, N.; Song, J.; Liu, Z.; Wang, L.; Jiang, G. Glycosylation of anthocyanins enhances the apoptosis of colon cancer cells by handicapping energy metabolism. BMC Complement Med. Ther. 2020, 20, 312. [CrossRef]

42. Esselen, M.; Fritz, J.; Hutter, M.; Teller, N.; Baechler, S.; Boettler, U.; Marczylo, T.H.; Gescher, A.J.; Marko, D. Anthocyanin-rich extracts suppress the DNA-damaging effects of topoisomerase poisons in human colon cancer cells. Mol. Nutr. Food Res. 2011, 55 (Suppl. 1), S143-S153. [CrossRef]

43. Lippert, E.; Ruemmele, P.; Obermeier, F.; Goelder, S.; Kunst, C.; Rogler, G.; Dunger, N.; Messmann, H.; Hartmann, A.; Endlicher, E. Anthocyanins Prevent Colorectal Cancer Development in a Mouse Model. Digestion 2017, 95, 275-280. [CrossRef]

44. Lala, G.; Malik, M.; Zhao, C.; He, J.; Kwon, Y.; Giusti, M.M.; Magnuson, B.A. Anthocyanin-rich extracts inhibit multiple biomarkers of colon cancer in rats. Nutr. Cancer 2006, 54, 84-93. [CrossRef]

45. Seeram, N.P.; Adams, L.S.; Hardy, M.L.; Heber, D. Total cranberry extract versus its phytochemical constituents: Antiproliferative and synergistic effects against human tumor cell lines. J. Agric. Food Chem. 2004, 52, 2512-2517. [CrossRef]

46. Malik, M.; Zhao, C.; Schoene, N.; Guisti, M.M.; Moyer, M.P.; Magnuson, B.A. Anthocyanin-rich extract from Aronia meloncarpa E induces a cell cycle block in colon cancer but not normal colonic cells. Nutr. Cancer 2003, 46, 186-196. [CrossRef]

47. Pool-Zobel, B.L.; Bub, A.; Schroder, N.; Rechkemmer, G. Anthocyanins are potent antioxidants in model systems but do not reduce endogenous oxidative DNA damage in human colon cells. Eur. J. Nutr. 1999, 38, 227-234. [CrossRef]

48. Wei, J.; Yu, W.; Hao, R.; Fan, J.; Gao, J. Anthocyanins from Aronia melanocarpa Induce Apoptosis in Caco-2 Cells through Wnt/beta-Catenin Signaling Pathway. Chem. Biodivers. 2020, 17, e2000654. [CrossRef]

49. Gill, N.K.; Rios, D.; Osorio-Camacena, E.; Mojica, B.E.; Kaur, B.; Soderstrom, M.A.; Gonzalez, M.; Plaat, B.; Poblete, C.; Kaur, N.; et al. Anticancer Effects of Extracts from Three Different Chokeberry Species. Nutr. Cancer 2021, 73, 1168-1174. [CrossRef]

50. Dai, J.; Patel, J.D.; Mumper, R.J. Characterization of blackberry extract and its antiproliferative and anti-inflammatory properties. J. Med. Food 2007, 10, 258-265. [CrossRef]

51. Elisia, I.; Kitts, D.D. Anthocyanins inhibit peroxyl radical-induced apoptosis in Caco-2 cells. Mol. Cell Biochem. 2008, 312, 139-145. [CrossRef]

52. Vilkickyte, G.; Raudone, L.; Petrikaite, V. Phenolic Fractions from Vaccinium vitis-idaea L. and Their Antioxidant and Anticancer Activities Assessment. Antioxidants 2020, 9, 1261-1278. [CrossRef]

53. Condello, M.; Pellegrini, E.; Spugnini, E.P.; Baldi, A.; Amadio, B.; Vincenzi, B.; Occhionero, G.; Delfine, S.; Mastrodonato, F.; Meschini, S. Anticancer activity of "Trigno M", extract of Prunus spinosa drupes, against in vitro 3D and in vivo colon cancer models. Biomed. Pharmacother. 2019, 118, 109281. [CrossRef]

54. Yi, W.; Fischer, J.; Akoh, C.C. Study of anticancer activities of muscadine grape phenolics in vitro. J. Agric. Food Chem. 2005, 53, 8804-8812. [CrossRef]

55. Mazewski, C.; Liang, K.; Gonzalez de Mejia, E. Comparison of the effect of chemical composition of anthocyanin-rich plant extracts on colon cancer cell proliferation and their potential mechanism of action using in vitro, in silico, and biochemical assays. Food Chem. 2018, 242, 378-388. [CrossRef] [PubMed]

56. Perez-Ortiz, J.M.; Alguacil, L.F.; Salas, E.; Hermosin-Gutierrez, I.; Gomez-Alonso, S.; Gonzalez-Martin, C. Antiproliferative and cytotoxic effects of grape pomace and grape seed extracts on colorectal cancer cell lines. Food Sci. Nutr. 2019, 7, $2948-2957$. [CrossRef] [PubMed]

57. Cai, H.; Marczylo, T.H.; Teller, N.; Brown, K.; Steward, W.P.; Marko, D.; Gescher, A.J. Anthocyanin-rich red grape extract impedes adenoma development in the Apc(Min) mouse: Pharmacodynamic changes and anthocyanin levels in the murine biophase. Eur. J. Cancer 2010, 46, 811-817. [CrossRef] [PubMed]

58. Kamei, H.; Hashimoto, Y.; Koide, T.; Kojima, T.; Hasegawa, M. Anti-tumor effect of methanol extracts from red and white wines. Cancer Biother. Radiopharm. 1998, 13, 447-452. [CrossRef] 
59. Signorelli, P.; Fabiani, C.; Brizzolari, A.; Paroni, R.; Casas, J.; Fabrias, G.; Rossi, D.; Ghidoni, R.; Caretti, A. Natural grape extracts regulate colon cancer cells malignancy. Nutr. Cancer 2015, 67, 494-503. [CrossRef]

60. Bobe, G.; Wang, B.; Seeram, N.P.; Nair, M.G.; Bourquin, L.D. Dietary anthocyanin-rich tart cherry extract inhibits intestinal tumorigenesis in APC(Min) mice fed suboptimal levels of sulindac. J. Agric. Food Chem. 2006, 54, 9322-9328. [CrossRef]

61. Symonds, E.L.; Konczak, I.; Fenech, M. The Australian fruit Illawarra plum (Podocarpus elatus Endl., Podocarpaceae) inhibits telomerase, increases histone deacetylase activity and decreases proliferation of colon cancer cells. Br. J. Nutr. 2013, 109, $2117-2125$. [CrossRef]

62. Charepalli, V.; Reddivari, L.; Vadde, R.; Walia, S.; Radhakrishnan, S.; Vanamala, J.K. Eugenia jambolana (Java Plum) Fruit Extract Exhibits Anti-Cancer Activity against Early Stage Human HCT-116 Colon Cancer Cells and Colon Cancer Stem Cells. Cancers 2016, 8, 29. [CrossRef]

63. Shin, D.Y.; Lee, W.S.; Lu, J.N.; Kang, M.H.; Ryu, C.H.; Kim, G.Y.; Kang, H.S.; Shin, S.C.; Choi, Y.H. Induction of apoptosis in human colon cancer HCT-116 cells by anthocyanins through suppression of Akt and activation of p38-MAPK. Int. J. Oncol. 2009, 35, 1499-1504.

64. Shin, D.Y.; Lu, J.N.; Kim, G.Y.; Jung, J.M.; Kang, H.S.; Lee, W.S.; Choi, Y.H. Anti-invasive activities of anthocyanins through modulation of tight junctions and suppression of matrix metalloproteinase activities in HCT-116 human colon carcinoma cells. Oncol. Rep. 2011, 25, 567-572.

65. Lee, Y.K.; Lee, W.S.; Kim, G.S.; Park, O.J. Anthocyanins are novel AMPKalpha1 stimulators that suppress tumor growth by inhibiting mTOR phosphorylation. Oncol. Rep. 2010, 24, 1471-1477. [PubMed]

66. Yun, J.W.; Lee, W.S.; Kim, M.J.; Lu, J.N.; Kang, M.H.; Kim, H.G.; Kim, D.C.; Choi, E.J.; Choi, J.Y.; Kim, H.G.; et al. Characterization of a profile of the anthocyanins isolated from Vitis coignetiae Pulliat and their anti-invasive activity on HT-29 human colon cancer cells. Food Chem. Toxicol. 2010, 48, 903-909. [CrossRef]

67. Lim, S.; Xu, J.; Kim, J.; Chen, T.Y.; Su, X.; Standard, J.; Carey, E.; Griffin, J.; Herndon, B.; Katz, B.; et al. Role of anthocyanin-enriched purple-fleshed sweet potato p40 in colorectal cancer prevention. Mol. Nutr. Food Res. 2013, 57, 1908-1917. [CrossRef] [PubMed]

68. Sugata, M.; Lin, C.Y.; Shih, Y.C. Anti-Inflammatory and Anticancer Activities of Taiwanese Purple-Fleshed Sweet Potatoes (Ipomoea batatas L. Lam) Extracts. Biomed. Res. Int. 2015, 2015, 768093. [CrossRef]

69. Hsu, C.P.; Shih, Y.T.; Lin, B.R.; Chiu, C.F.; Lin, C.C. Inhibitory effect and mechanisms of an anthocyanins- and anthocyanidins-rich extract from purple-shoot tea on colorectal carcinoma cell proliferation. J. Agric. Food Chem. 2012, 60, 3686-3692. [CrossRef] [PubMed]

70. Olsen, H.; Grimmer, S.; Aaby, K.; Saha, S.; Borge, G.I. Antiproliferative effects of fresh and thermal processed green and red cultivars of curly kale (Brassica oleracea L. convar. acephala var. sabellica). J. Agric. Food. Chem. 2012, 60, 7375-7383. [CrossRef] [PubMed]

71. Jing, P.; Qian, B.; Zhao, S.; Qi, X.; Ye, L.; Monica Giusti, M.; Wang, X. Effect of glycosylation patterns of Chinese eggplant anthocyanins and other derivatives on antioxidant effectiveness in human colon cell lines. Food Chem. 2015, 172, 183-189. [CrossRef]

72. Rezaei, P.F.; Fouladdel, S.; Hassani, S.; Yousefbeyk, F.; Ghaffari, S.M.; Amin, G.; Azizi, E. Induction of apoptosis and cell cycle arrest by pericarp polyphenol-rich extract of Baneh in human colon carcinoma HT29 cells. Food Chem. Toxicol. 2012, 50, 1054-1059. [CrossRef]

73. Bars-Cortina, D.; Martinez-Bardaji, A.; Macia, A.; Motilva, M.J.; Pinol-Felis, C. Consumption evaluation of one apple flesh a day in the initial phases prior to adenoma/adenocarcinoma in an azoxymethane rat colon carcinogenesis model. J. Nutr. Biochem. 2020, 83, 108418. [CrossRef]

74. Renis, M.; Calandra, L.; Scifo, C.; Tomasello, B.; Cardile, V.; Vanella, L.; Bei, R.; La Fauci, L.; Galvano, F. Response of cell cycle/stress-related protein expression and DNA damage upon treatment of $\mathrm{CaCo}_{2}$ cells with anthocyanins. Br. J. Nutr. 2008, 100, 27-35. [CrossRef]

75. Briviba, K.; Abrahamse, S.L.; Pool-Zobel, B.L.; Rechkemmer, G. Neurotensin-and EGF-induced metabolic activation of colon carcinoma cells is diminished by dietary flavonoid cyanidin but not by its glycosides. Nutr. Cancer 2001, 41, 172-179. [CrossRef]

76. Cvorovic, J.; Tramer, F.; Granzotto, M.; Candussio, L.; Decorti, G.; Passamonti, S. Oxidative stress-based cytotoxicity of delphinidin and cyanidin in colon cancer cells. Arch. Biochem. Biophys. 2010, 501, 151-157. [CrossRef]

77. Zhang, Y.; Seeram, N.P.; Lee, R.; Feng, L.; Heber, D. Isolation and identification of strawberry phenolics with antioxidant and human cancer cell antiproliferative properties. J. Agric. Food Chem. 2008, 56, 670-675. [CrossRef] [PubMed]

78. Baster, Z.; Li, L.; Kukkurainen, S.; Chen, J.; Pentikainen, O.; Gyorffy, B.; Hytonen, V.P.; Zhu, H.; Rajfur, Z.; Huang, C. Cyanidin-3glucoside binds to talin and modulates colon cancer cell adhesions and 3D growth. FASEB J. 2020, 34, 2227-2237. [CrossRef] [PubMed]

79. Hagiwara, A.; Miyashita, K.; Nakanishi, T.; Sano, M.; Tamano, S.; Kadota, T.; Koda, T.; Nakamura, M.; Imaida, K.; Ito, N.; et al. Pronounced inhibition by a natural anthocyanin, purple corn color, of 2-amino-1-methyl-6-phenylimidazo[4,5-b]pyridine (PhIP)-associated colorectal carcinogenesis in male F344 rats pretreated with 1,2-dimethylhydrazine. Cancer Lett. 2001, 171, 17-25. [CrossRef]

80. Lazze, M.C.; Savio, M.; Pizzala, R.; Cazzalini, O.; Perucca, P.; Scovassi, A.I.; Stivala, L.A.; Bianchi, L. Anthocyanins induce cell cycle perturbations and apoptosis in different human cell lines. Carcinogenesis 2004, 25, 1427-1433. [CrossRef] 
81. Yun, J.M.; Afaq, F.; Khan, N.; Mukhtar, H. Delphinidin, an anthocyanidin in pigmented fruits and vegetables, induces apoptosis and cell cycle arrest in human colon cancer HCT116 cells. Mol. Carcinog. 2009, 48, 260-270. [CrossRef]

82. Zhang, Z.; Pan, Y.; Zhao, Y.; Ren, M.; Li, Y.; Lu, G.; Wu, K.; He, S. Delphinidin modulates JAK/STAT3 and MAPKinase signaling to induce apoptosis in HCT116 cells. Environ. Toxicol. 2021, 36, 1557-1566. [CrossRef]

83. Forester, S.C.; Waterhouse, A.L. Gut metabolites of anthocyanins, gallic acid, 3-O-methylgallic acid, and 2,4,6-trihydroxybenzaldehyde, inhibit cell proliferation of Caco-2 cells. J. Agric. Food Chem. 2010, 58, 5320-5327. [CrossRef]

84. Forester, S.C.; Choy, Y.Y.; Waterhouse, A.L.; Oteiza, P.I. The anthocyanin metabolites gallic acid, 3-O-methylgallic acid, and 2,4,6-trihydroxybenzaldehyde decrease human colon cancer cell viability by regulating pro-oncogenic signals. Mol. Carcinog. 2014, 53, 432-439. [CrossRef]

85. Kubow, S.; Iskandar, M.M.; Melgar-Bermudez, E.; Sleno, L.; Sabally, K.; Azadi, B.; How, E.; Prakash, S.; Burgos, G.; Felde, T.Z. Effects of Simulated Human Gastrointestinal Digestion of Two Purple-Fleshed Potato Cultivars on Anthocyanin Composition and Cytotoxicity in Colonic Cancer and Non-Tumorigenic Cells. Nutrients 2017, 9, 953-980. [CrossRef]

86. Shi, N.; Chen, F.; Zhang, X.; Clinton, S.K.; Tang, X.; Sun, Z.; Chen, T. Suppression of Oxidative Stress and NFkappaB/MAPK Signaling by Lyophilized Black Raspberries for Esophageal Cancer Prevention in Rats. Nutrients 2017, 9, 413-427. [CrossRef]

87. Philpott, M.; Lim, C.C.; Ferguson, L.R. Dietary protection against free radicals: A case for multiple testing to establish structureactivity relationships for antioxidant potential of anthocyanic plant species. Int. J. Mol. Sci. 2009, 10, 1081-1103. [CrossRef]

88. Wang, L.S.; Stoner, G.D. Anthocyanins and their role in cancer prevention. Cancer Lett. 2008, 269, 281-290. [CrossRef]

89. Bueno, J.M.; Saez-Plaza, P.; Ramos-Escudero, F.; Jimenez, A.M.; Fett, R.; Asuero, A.G. Analysis and Antioxidant Capacity of Anthocyanin Pigments. Part II: Chemical Structure, Color, and Intake of Anthocyanins. Crit. Rev. Anal. Chem. 2012, 42, 126-151. [CrossRef]

90. Quintos, L.; Lee, I.A.; Kim, H.J.; Lim, J.S.; Park, J.; Sung, M.K.; Seo, Y.R.; Kim, J.S. Significance of p27 as potential biomarker for intracellular oxidative status. Nutr. Res. Pract. 2010, 4, 351-355. [CrossRef]

91. Sido, A.; Radhakrishnan, S.; Kim, S.W.; Eriksson, E.; Shen, F.; Li, Q.; Bhat, V.; Reddivari, L.; Vanamala, J.K.P. A food-based approach that targets interleukin-6, a key regulator of chronic intestinal inflammation and colon carcinogenesis. J. Nutr. Biochem. 2017, 43, 11-17. [CrossRef]

92. Teller, N.; Thiele, W.; Boettler, U.; Sleeman, J.; Marko, D. Delphinidin inhibits a broad spectrum of receptor tyrosine kinases of the ErbB and VEGFR family. Mol. Nutr. Food Res. 2009, 53, 1075-1083. [CrossRef]

93. Teller, N.; Thiele, W.; Marczylo, T.H.; Gescher, A.J.; Boettler, U.; Sleeman, J.; Marko, D. Suppression of the kinase activity of receptor tyrosine kinases by anthocyanin-rich mixtures extracted from bilberries and grapes. J. Agric. Food Chem. 2009, 57, 3094-3101. [CrossRef]

94. Hou, D.X.; Kai, K.; Li, J.J.; Lin, S.; Terahara, N.; Wakamatsu, M.; Fujii, M.; Young, M.R.; Colburn, N. Anthocyanidins inhibit activator protein 1 activity and cell transformation: Structure-activity relationship and molecular mechanisms. Carcinogenesis 2004, 25, 29-36. [CrossRef]

95. Zhou, Y.; Xia, L.; Wang, H.; Oyang, L.; Su, M.; Liu, Q.; Lin, J.; Tan, S.; Tian, Y.; Liao, Q.; et al. Cancer stem cells in progression of colorectal cancer. Oncotarget 2018, 9, 33403-33415. [CrossRef]

96. Wang, L.S.; Arnold, M.; Huang, Y.W.; Sardo, C.; Seguin, C.; Martin, E.; Huang, T.H.; Riedl, K.; Schwartz, S.; Frankel, W.; et al. Modulation of genetic and epigenetic biomarkers of colorectal cancer in humans by black raspberries: A phase I pilot study. Clin. Cancer Res. 2011, 17, 598-610. [CrossRef] [PubMed]

97. Mace, T.A.; King, S.A.; Ameen, Z.; Elnaggar, O.; Young, G.; Riedl, K.M.; Schwartz, S.J.; Clinton, S.K.; Knobloch, T.J.; Weghorst, C.M.; et al. Bioactive compounds or metabolites from black raspberries modulate T lymphocyte proliferation, myeloid cell differentiation and Jak/STAT signaling. Cancer Immunol. Immunother. 2014, 63, 889-900. [CrossRef] [PubMed]

98. Mazewski, C.; Kim, M.S.; Gonzalez de Mejia, E. Anthocyanins, delphinidin-3-O-glucoside and cyanidin-3-O-glucoside, inhibit immune checkpoints in human colorectal cancer cells in vitro and in silico. Sci. Rep. 2019, 9, 11560. [CrossRef] [PubMed]

99. Selma, M.V.; Espin, J.C.; Tomas-Barberan, F.A. Interaction between phenolics and gut microbiota: Role in human health. J Agric. Food Chem. 2009, 57, 6485-6501. [CrossRef]

100. Jennings, A.; Koch, M.; Jensen, M.K.; Bang, C.; Kassubek, J.; Muller, H.P.; Nothlings, U.; Franke, A.; Lieb, W.; Cassidy, A. The role of the gut microbiome in the association between habitual anthocyanin intake and visceral abdominal fat in population-level analysis. Am. J. Clin. Nutr. 2020, 111, 340-350. [CrossRef]

101. Peng, Y.; Yan, Y.; Wan, P.; Chen, D.; Ding, Y.; Ran, L.; Mi, J.; Lu, L.; Zhang, Z.; Li, X.; et al. Gut microbiota modulation and anti-inflammatory properties of anthocyanins from the fruits of Lycium ruthenicum Murray in dextran sodium sulfate-induced colitis in mice. Free Radic. Biol. Med. 2019, 136, 96-108. [CrossRef]

102. Liu, F.; Wang, T.T.Y.; Tang, Q.; Xue, C.; Li, R.W.; Wu, V.C.H. Malvidin 3-Glucoside Modulated Gut Microbial Dysbiosis and Global Metabolome Disrupted in a Murine Colitis Model Induced by Dextran Sulfate Sodium. Mol. Nutr. Food Res. 2019, 63, e1900455. [CrossRef]

103. Si, X.; Bi, J.; Chen, Q.; Cui, H.; Bao, Y.; Tian, J.; Shu, C.; Wang, Y.; Tan, H.; Zhang, W.; et al. Effect of Blueberry Anthocyanin-Rich Extracts on Peripheral and Hippocampal Antioxidant Defensiveness: The Analysis of the Serum Fatty Acid Species and Gut Microbiota Profile. J. Agric. Food Chem. 2021, 69, 3658-3666. [CrossRef]

104. Nakano, H.; Wu, S.; Sakao, K.; Hara, T.; He, J.; Garcia, S.; Shetty, K.; Hou, D.X. Bilberry Anthocyanins Ameliorate NAFLD by Improving Dyslipidemia and Gut Microbiome Dysbiosis. Nutrients 2020, 12, 3252-3268. [CrossRef] 
105. Barnett, M.P.G.; Young, W.; Armstrong, K.; Brewster, D.; Cooney, J.M.; Ellett, S.; Espley, R.V.; Laing, W.; Maclean, P.; McGhie, T.; et al. A Polyphenol Enriched Variety of Apple Alters Circulating Immune Cell Gene Expression and Faecal Microbiota Composition in Healthy Adults: A Randomized Controlled Trial. Nutrients 2021, 13, 1092-1110. [CrossRef]

106. Ge, J.; Yue, X.; Wang, S.; Chi, J.; Liang, J.; Sun, Y.; Gao, X.; Yue, P. Nanocomplexes composed of chitosan derivatives and beta-Lactoglobulin as a carrier for anthocyanins: Preparation, stability and bioavailability in vitro. Food Res. Int. 2019, 116, 336-345. [CrossRef]

107. Oidtmann, J.; Schantz, M.; Mader, K.; Baum, M.; Berg, S.; Betz, M.; Kulozik, U.; Leick, S.; Rehage, H.; Schwarz, K.; et al. Preparation and comparative release characteristics of three anthocyanin encapsulation systems. J. Agric. Food Chem. 2012, 60, 844-851. [CrossRef]

108. Baum, M.; Schantz, M.; Leick, S.; Berg, S.; Betz, M.; Frank, K.; Rehage, H.; Schwarz, K.; Kulozik, U.; Schuchmann, H.; et al. Is the antioxidative effectiveness of a bilberry extract influenced by encapsulation? J. Sci. Food Agric. 2014, 94, 2301-2307. [CrossRef]

109. Ma, Y.; Feng, Y.; Zeng, W.; Luo, H. Anthocyanin Encapsulated by Ferulic Acid-Grafted-Maltodextrin (FA-g-MD) Microcapsules Potentially Improved its Free Radical Scavenging Capabilities Against $\mathrm{H}_{2} \mathrm{O}_{2}$-Induced Oxidative Stress. Molecules 2019, 24, 1596-1608. [CrossRef]

110. Aqil, F.; Jeyabalan, J.; Agrawal, A.K.; Kyakulaga, A.H.; Munagala, R.; Parker, L.; Gupta, R.C. Exosomal delivery of berry anthocyanidins for the management of ovarian cancer. Food Funct. 2017, 8, 4100-4107. [CrossRef]

111. Wu, Y.; Han, Y.; Tao, Y.; Li, D.; Xie, G.; Show, P.L.; Lee, S.Y. In vitro gastrointestinal digestion and fecal fermentation reveal the effect of different encapsulation materials on the release, degradation and modulation of gut microbiota of blueberry anthocyanin extract. Food Res. Int. 2020, 132, 109098. [CrossRef]

112. Fernandes, I.; Marques, F.; de Freitas, V.; Mateus, N. Antioxidant and antiproliferative properties of methylated metabolites of anthocyanins. Food Chem. 2013, 141, 2923-2933. [CrossRef] [PubMed]

113. Grimes, K.L.; Stuart, C.M.; McCarthy, J.J.; Kaur, B.; Cantu, E.J.; Forester, S.C. Enhancing the Cancer Cell Growth Inhibitory Effects of Table Grape Anthocyanins. J. Food Sci. 2018, 83, 2369-2374. [CrossRef] [PubMed]

114. Fantini, M.; Benvenuto, M.; Masuelli, L.; Frajese, G.V.; Tresoldi, I.; Modesti, A.; Bei, R. In vitro and in vivo antitumoral effects of combinations of polyphenols, or polyphenols and anticancer drugs: Perspectives on cancer treatment. Int. J. Mol. Sci. 2015, 16, 9236-9282. [CrossRef] [PubMed]

115. Singh, C.K.; Siddiqui, I.A.; El-Abd, S.; Mukhtar, H.; Ahmad, N. Combination chemoprevention with grape antioxidants. Mol. Nutr. Food Res. 2016, 60, 1406-1415. [CrossRef]

116. Yin, H.; Wang, L.; Wu, M.; Liu, Y.; Li, N.; Chen, T. Cyanidin-3-O-glucoside chloride acts synergistically with luteolin to inhibit the growth of colon and breast carcinoma cells. Pharmazie 2019, 74, 54-61.

117. Koh, J.; Xu, Z.; Wicker, L. Blueberry pectin and increased anthocyanins stability under in vitro digestion. Food Chem. 2020, 302, 125343. [CrossRef]

118. Feng, R.; Wang, S.Y.; Shi, Y.H.; Fan, J.; Yin, X.M. Delphinidin induces necrosis in hepatocellular carcinoma cells in the presence of 3-methyladenine, an autophagy inhibitor. J. Agric. Food Chem. 2010, 58, 3957-3964. [CrossRef]

119. Wang, G.; Fu, X.L.; Wang, J.J.; Guan, R.; Sun, Y.; Tony To, S.S. Inhibition of glycolytic metabolism in glioblastoma cells by Pt3glc combinated with PI3K inhibitor via SIRT3-mediated mitochondrial and PI3K/Akt-MAPK pathway. J. Cell Physiol. 2019, 234, 5888-5903. [CrossRef]

120. Yoshino, Y.; Yuan, B.; Okusumi, S.; Aoyama, R.; Murota, R.; Kikuchi, H.; Takagi, N.; Toyoda, H. Enhanced cytotoxic effects of arsenite in combination with anthocyanidin compound, delphinidin, against a human leukemia cell line, HL-60. Chem. Biol. Interact. 2018, 294, 9-17. [CrossRef]

121. Yuan, B.; Okusumi, S.; Yoshino, Y.; Moriyama, C.; Tanaka, S.; Hirano, T.; Takagi, N.; Toyoda, H. Delphinidin induces cytotoxicity and potentiates cytocidal effect in combination with arsenite in an acute promyelocytic leukemia NB4 cell line. Oncol. Rep. 2015, 34, 431-438. [CrossRef]

122. Lavefve, L.; Howard, L.R.; Carbonero, F. Berry polyphenols metabolism and impact on human gut microbiota and health. Food Funct. 2020, 11, 45-65. [CrossRef]

123. Bresciani, L.; Angelino, D.; Vivas, E.I.; Kerby, R.L.; Garcia-Viguera, C.; Del Rio, D.; Rey, F.E.; Mena, P. Differential Catabolism of an Anthocyanin-Rich Elderberry Extract by Three Gut Microbiota Bacterial Species. J. Agric. Food Chem. 2020, 68, 1837-1843. [CrossRef] 